\title{
Transgenerational Transmission of Trauma: Psychiatric Evaluation of Offspring of Former "Comfort Women," Survivors of the Japanese Military Sexual Slavery during World War II
}

\author{
Jeewon Lee', Young-Sook Kwak², Yoon-Jung Kim³ ${ }^{3}$ Eun-Ji Kim, E Jin Park ${ }^{5}$, \\ Yunmi Shin ${ }^{6}$, Bun-Hee Lee ${ }^{7}$, So Hee Lee ${ }^{8}$, Hee Yeon Jung ${ }^{9}$, Inseon Lee ${ }^{10}$, \\ Jung Im Hwang ${ }^{10}$, Dongsik Kim ${ }^{10}$, and Soyoung Irene Lee ${ }^{1 凶}$ \\ ${ }^{1}$ Department of Psychiatry, Soonchunhyang University Bucheon Hospital, Bucheon, Republic of Korea \\ ${ }^{2}$ Department of Psychiatry, Jeju National University College of Medicine, Jeju, Republic of Korea \\ ${ }^{3}$ Mentor Clinic, Seoul, Republic of Korea \\ ${ }^{4}$ Maumtodac Clinic, Ansan, Republic of Korea \\ ${ }^{5}$ Department of Psychiatry, Incheon St. Mary's Hospital, Incheon, Republic of Korea \\ ${ }^{6}$ Department of Psychiatry, Ajou University School of Medicine, Suwon, Republic of Korea \\ ${ }^{7}$ Maum \& Maum Clinic, Seoul, Republic of Korea \\ ${ }^{8}$ Department of Psychiatry, National Medical Center, Seoul, Republic of Korea \\ ${ }^{9}$ Department of Psychiatry, SMG-SNU Boramae Medical Center, Seoul National University College of Medicine, Seoul, Republic of Korea \\ ${ }^{10}$ Korean Women's Development Institute, Seoul, Republic of Korea
}

"Comfort women" are survivors of sexual slavery by the Imperial Japanese Army during World War II, who endured extensive trauma including massive rape and physical torture. While previous studies have been focused on the trauma of the survivors themselves, the effects of the trauma on the offspring has never been evaluated before. In this article, we reviewed the first study on the offspring of former "comfort women" and aimed to detect the evidence of transgenerational transmission of trauma. In-depth psychiatric interviews and the Structured Clinical Interview for DSM-5 Axis I Disorders were conducted with six offspring of former "comfort women." Among the six participants, five suffered from at least one psychiatric disorder including major depressive disorder, panic disorder, posttraumatic stress disorder, adjustment disorder, insomnia disorder, somatic symptom disorder, and alcohol use disorder. Participants showed similar shame and hyperarousal symptoms as their mothers regarding stimuli related to the "comfort woman" issue. Increased irritability, problems with aggression control, negative worldview, and low self-esteem were evident in the children of mothers with posttraumatic stress disorder. Finding evidence of transgenerational transmission of trauma in offspring of "comfort women" is important. Future studies should include more samples and adopt a more objective method.

Psychiatry Investig 2019;16(3):249-253

Key Words Comfort women, Second generation, Transgenerational transmission of trauma.

\section{INTRODUCTION}

"Comfort women" are survivors of sexual slavery by the Imperial Japanese Army during World War II, who endured extensive trauma including massive rape and physical torture. ${ }^{1}$ After the trauma, survivors suffered from lifelong guilt

\footnotetext{
Received: May 14, 2018 Revised: January 8, 2019

Accepted: January 21, 2019

$\triangle$ Correspondence: Soyoung Irene Lee, MD, PhD

Department of Psychiatry, Soonchunhyang University Bucheon Hospital, 170 Jomaru-ro, Bucheon 14584, Republic of Korea

Tel: +82-32-621-5063, Fax: +82-32-621-6950, E-mail: irenelee@schmc.ac.kr

(a) This is an Open Access article distributed under the terms of the Creative Commons Attribution Non-Commercial License (https://creativecommons.org/licenses/bync/4.0) which permits unrestricted non-commercial use, distribution, and reproduction in any medium, provided the original work is properly cited.
}

and stigma, and had problems in emotional regulation and impulse control. ${ }^{1}$ They showed high prevalence of psychiatric disorders, especially posttraumatic stress disorder (PTSD). However, the consequences of such extreme trauma may not be limited to the survivors themselves. Cumulating evidence suggests that effects of traumatic experiences can be transmitted to subsequent generations. ${ }^{2}$

The idea that a parental traumatic experience could perpetuate from one generation to the next was first introduced in studies on offspring of Holocaust survivors. ${ }^{3}$ Many studies on second generation Holocaust survivors reported problematic psychological profile of the second-generation survivors which were mostly personality challenges and generalized approaches to life: ${ }^{4}$ negative worldview, difficulties with separation- 
individuation, ${ }^{5}$ difficulties with coping under pressure, and neurotic conflicts. ${ }^{6}$ Especially children of Holocaust survivors with PTSD showed increased susceptibility to posttraumatic stress disorder, ${ }^{7}$ as well as anxiety and depression, compared to the children of Holocaust survivors without PTSD. ${ }^{2}$

Evidence of transgenerational transmission of trauma have also been found in descendants of war veterans, ${ }^{8}$ torture victims ${ }^{9}$ and refugees. ${ }^{10}$ Previous studies showed that children of combat-veterans with PTSD often manifested depression, anxiety, hyperactivity, delinquency, poor socialization, and academic difficulties compared to children of fathers without PTSD. ${ }^{11}$ In children of Southeast Asian refugees, maternal traumatic distress was associated with poor child mental health outcomes including depressive symptoms, antisocial and delinquent behaviors. ${ }^{12}$

While previous studies regarding the "comfort women" have been focused on the trauma of the survivors themselves, the effects of the trauma on the offspring has never been evaluated before. In this article, we reviewed the first study which conducted a psychiatric evaluation on the offspring of former "comfort women" and aimed to detect the evidence of transgenerational transmission of trauma.

\section{METHODS}

As a substudy of "A Comprehensive Study to Resolve the Japanese Military 'Comfort Women' Issue (II)" by the Korean Women's Development Institute, psychiatrists from Special Committee for Gender-Equality and Family of Korean Neuropsychiatry Association conducted a study on 20 of the 38 registered former "comfort women" alive in South Korea in 2016. Full details of the study on the former "comfort women" have been described elsewhere. 1 After interviewing the 20 former "comfort women," we explained the aims of the study and asked if we could contact their children. We tried to include all biological and non-biological children of all 20 former "comfort women' who participated in the prior study. With the consent of the survivors, we contacted the children and asked for their participation in the study. This study was approved by the Ethics Committee of Soonchunhyang University Bucheon Hospital (2016-06-017).

Among 36 biological children of the 20 former "comfort women", five participated in the study: 14 didn't know their mothers' past as a "comfort woman;" 8 refused to participate; 5 were excluded because their mothers refused them to participate, 3 were lost contact, and 1 was living abroad. All 17 non-biological children of the 20 participants were excluded in the study: 8 were lost contact, 7 were living abroad, 2 refused to participate. As an exception, 1 biological child of a registered former "comfort women" who couldn't partici- pate in the prior study due to health problems agreed to participate in the study. As a result, a total of six biological children of former "comfort women" were interviewed. All participants were assured that their anonymity would be maintained.

A group of two, consisting of two psychiatrists or one psychiatrist and one clinical psychologist interviewed the participants. In-depth psychiatric interviews were conducted to identify evidence of transgenerational transmission of trauma in the participants. The Structured Clinical Interview for DSM-5 Axis I Disorders (SCID-I) was used to assess current (30 days) and lifetime diagnosis of psychiatric disorders. ${ }^{13}$

Participants also completed a questionnaire containing sociodemographic information, Center for Epidemiologic Studies Depression Scale (CES-D) and Patient Health Questionnaire 15 (PHQ-15). CES-D is a 20-item measure that rates the depressive symptom of the participants. PHQ-15 is a 15 -item measure that evaluates the presence and severity of the somatic symptoms of the participants.

\section{RESULTS}

Sociodemographic and clinical characteristics of the participants are shown in Table 1. The mean age of the six participants were $66.3(\mathrm{SD}=6.43)$. Three of them were daughters and three of them were sons of the former "comfort women".

The psychiatric diagnoses of the individual participants are shown in Table 2. Five of them had suffered from at least 1 psychiatric disorder in their lives. The three participants (A, B, C) whose mothers suffered from PTSD seemed most affected by their mothers' trauma. The stories of the three participants are summarized.

\section{A}

A's father was married when he met A's mother. Her father had difficulty controlling his anger and he became very violent when he got angry. Especially when her father found out that her mother was a former "comfort woman" he became furious and beat up her mother like a mad man. A remembers always being poor and anxious when she was young because not a single day passed without trouble. She felt unhappy all the time and resented her parents for always fighting.

After A became an adult, she used violence against her lovers when she became angry. She hated herself for being so violent but couldn't change. Her violence even continued towards her spouse during her marriage, and she eventually got divorced.

A's mother ran away from her father few years ago and is living with A now. She seemed overwhelmed by her responsibility of taking care of her mother. She experienced depression in the past and was still suffering from panic attacks and 
insomnia. She often drove recklessly and cursed at people when she got angry in the past.

During the interview, we could notice that A resembled

Table 1. Sociodemographic and clinical characteristics of the participants $(\mathrm{N}=6)$

\begin{tabular}{|c|c|c|}
\hline Variables & Mean or $\mathrm{N}$ & $\mathrm{SD}$ or $\%$ \\
\hline Age & 66.3 & 6.43 \\
\hline \multicolumn{3}{|l|}{ Gender } \\
\hline Male & 3 & 50 \\
\hline Female & 3 & 50 \\
\hline \multicolumn{3}{|l|}{ Education level } \\
\hline Elementary school & 0 & 0 \\
\hline Middle school & 0 & 0 \\
\hline High school & 3 & 50 \\
\hline University or more & 3 & 50 \\
\hline \multicolumn{3}{|l|}{ Economic status } \\
\hline Low & 3 & 50 \\
\hline Middle & 2 & 33.3 \\
\hline High & 1 & 16.7 \\
\hline \multicolumn{3}{|l|}{ Marital status } \\
\hline Married & 4 & 66.7 \\
\hline Divorced & 1 & 16.7 \\
\hline Widowed & 1 & 16.7 \\
\hline \multicolumn{3}{|l|}{ CES-D } \\
\hline Normal (0-20) & 3 & 50 \\
\hline Moderate (21-24) & 1 & 16.7 \\
\hline Severe $\left(25^{-}\right)$ & 2 & 33.3 \\
\hline \multicolumn{3}{|l|}{ PHQ-15 } \\
\hline Minimal (0-4) & 1 & 16.7 \\
\hline Low (5-9) & 1 & 16.7 \\
\hline Moderate (10-19) & 2 & 33.3 \\
\hline Severe (15-30) & 2 & 33.3 \\
\hline
\end{tabular}

SD: standard deviation, CES-D: Center for Epidermiological Studies-Depression Scale, PHQ-15: Patient Health Questionnaire-15 her mother very much. When her mother became agitated when recalling her experience as a "comfort woman," A became very anxious and angry a well. Also, A was very protective about her personal information and clarified with us repetitively of the anonymity of the interview. She seemed very similar to her mother who constantly expressed strong distrust towards the world.

\section{B}

B's father was a married man when he met B's mother. B's father lived with his family and visited B and his mother occasionally. His parents always got into an argument when his father came home, and his mother cried for days after his father left. His mother was always very labile and had drinking problems, so he always felt unsecure and anxious when he was young. His father became very violent and looked down on his mother since one point, and he found out later that it was when his father found out his mother was a "comfort woman."

Like his mother, B had difficulty controlling his anger and had drinking problems. He almost became a gang member when he was in high school. When he was drafted into the military, he didn't adapt very well because of his anger problem and was confined in the guardhouse. After he was discharged from the military, he became addicted to alcohol and experienced depression.

C

C's mother married C's father who had several children from his first marriage. $\mathrm{C}$ remembers his mother always losing her temper unexpectedly. One time when he was young, his mother got so mad that she cried out "let's kill ourselves together" and lit a match and almost burned down the house. $\mathrm{C}$ remembered being so scared every time his mother got furious.

When C's mother was pregnant with $\mathrm{C}$, she bumped into a soldier and almost fainted with fright. Later when $\mathrm{C}$ was

Table 2. Psychiatric diagnoses of the individual participants $(\mathrm{N}=6)$

\begin{tabular}{|c|c|c|c|c|c|c|c|c|c|c|c|c|c|c|c|}
\hline & \multicolumn{14}{|c|}{ Psychiatric disorders } & \multirow{3}{*}{ Maternal PTSD } \\
\hline & \multicolumn{2}{|c|}{ MDD } & \multicolumn{2}{|c|}{ Panic } & \multicolumn{2}{|c|}{ PTSD } & \multicolumn{2}{|c|}{ Adjustment } & \multicolumn{2}{|c|}{ Insomnia } & \multicolumn{2}{|c|}{ Somatic } & \multicolumn{2}{|c|}{ Alcohol } & \\
\hline & $\mathrm{L}$ & $\mathrm{C}$ & $\mathrm{L}$ & $\mathrm{C}$ & $\mathrm{L}$ & $\mathrm{C}$ & $\mathrm{L}$ & $\mathrm{C}$ & $\mathrm{L}$ & $\mathrm{C}$ & $\mathrm{L}$ & $\mathrm{C}$ & $\mathrm{L}$ & $\mathrm{C}$ & \\
\hline A & $\mathrm{O}$ & $\mathrm{O}$ & $\mathrm{O}$ & & & & $\mathrm{O}$ & $\mathrm{O}$ & & & $\mathrm{O}$ & $\mathrm{O}$ & & & $\mathrm{O}$ \\
\hline B & $\mathrm{O}$ & & & & $\mathrm{O}$ & & & & & & & & $\mathrm{O}$ & & $\mathrm{O}$ \\
\hline $\mathrm{C}$ & & & & & & & & & $\mathrm{O}$ & $\mathrm{O}$ & $\mathrm{O}$ & & & & $\mathrm{O}$ \\
\hline $\mathrm{D}$ & & & & & & & & & & & & & & & \\
\hline $\mathrm{E}$ & $\mathrm{O}$ & & & & & & & & & & & & & & \\
\hline $\mathrm{F}$ & & & & & & & & & $\mathrm{O}$ & $\mathrm{O}$ & & & & & \\
\hline
\end{tabular}

MDD: major depressive disorder, Panic: panic disorder, PTSD: posttraumatic stress disorder, Adjustment: adjustment disorder, Insomnia: insomnia disorder, Somatic: somatic symptom disorder, Alcohol: alcohol use disorder 
diagnosed with a chronic disease, she blamed herself and the event which she was so startled by the soldier when she was pregnant. $\mathrm{C}$ resented his life for being diagnosed with such a chronic disease and suffered from various nonspecific physical symptoms. When C's child was also diagnosed with a chronic disease different from the one $\mathrm{C}$ was diagnosed with, $\mathrm{C}$ also blamed himself for it.

After C found out that his mother was a "comfort woman," he felt stigmatized. At the same time, he felt sorry for his mother. His siblings also feel very stigmatized and hate to be exposed as children of a "comfort woman." C and his siblings have conflicts over taking care of C's mother. C is currently having problem sleeping and reported having suicidal ideation for a very long time.

\section{DISCUSSION}

Among the six offspring of former "comfort women," five of them suffered from at least one psychiatric disorder including major depressive disorder, panic disorder, posttraumatic stress disorder, adjustment disorder, insomnia disorder, somatic symptom disorder, and alcohol use disorder. The evidence of transgenerational transmission of trauma, which we found in the participants whose mothers suffered from PTSD, can be summarized as following. First, although the participants had not been traumatized themselves, they showed symptoms of hyper-vigilance including increased irritability and problems with aggression control, resembling their mothers. They also suffered from similar shame and stigma as their mothers regarding stimuli related to the "comfort woman" issue. Second, the participants showed a defiant and accusatory stance towards the world. Survivors who lived their lives with anger and resentment are expected to inculcate pronounced paranoia and negative worldview in their children. ${ }^{14}$ Third, the participants seemed to have internalized the values of self-recrimination through their guilt-ridden mothers. Parental modeling of guilt could result in self-directed loathing and low self-esteem in the second generation. ${ }^{14}$

How can offspring of former "comfort women," who did not experience the trauma directly, suffer its consequences? Mechanisms of the transgenerational transmission of trauma are not conclusive. Important components that could have mediated the process of the transmission of the traumatic experiences in the participants are the inadequate psychological parenting by the traumatized mother; the biological vulnerability inherited by the mother; and the secondary-traumatization.

First, inadequate psychological parenting by the traumatized mother can have a detrimental effect on the development and well-being of the children. ${ }^{15}$ Traumatic experience could interfere with one's positive childrearing behavior and lead to maladaptive parenting. ${ }^{16}$ Less family cohesion and greater family conflict are reported in families with a traumatized parent. ${ }^{17}$ Especially parents with PTSD have major difficulties in providing an adequate maturational environment for their children. Avoidance and psychic numbing could result in emotional and physical withdrawal from the children. ${ }^{18}$ Survivors could be neglectful and insensitive to daily matters of the children as the matters would always be so trivial compared to the trauma. As mothers fail to maintain an adequate level of responsiveness toward the children, children could feel unprotected and insecure. ${ }^{14}$ Symptoms of hypervigilance of the survivors resulting in anger outbursts and hostility should have been frightening and incomprehensible to the children. Also, survivors could be overprotective and always in fear of their children's safety, making their children difficult to develop a sense self-efficacy and autonomy. ${ }^{15}$

Second, participants could have inherited the biological vulnerability by their mothers. Traumatic stress alters the integrity of the hypothalamic-pituitary-adrenal (HPA) axis. Previous studies showed that offspring of trauma survivors with PTSD have significantly lower urinary cortisol excretion and salivary cortisol level than offspring of survivors without PTSD. ${ }^{19}$ Furthermore, a growing body of evidence explains the mechanism of transgenerational transmission of trauma with epigenetics. ${ }^{20}$ It has been suggested that heritable changes in gene expression can be made as a result of environmental stress or major emotional trauma. ${ }^{21}$ Parents can pass on such acquired characteristics just like genetic characteristics. ${ }^{20}$

Third, participants could have been indirectly traumatized after finding out that their mothers were former "comfort women." Vivid details of the atrocities committed by the Japanese military has been testified by the survivors and are known to the public. Participants would have been traumatized by visualizing what their mothers had experienced. Furthermore, the unsettled controversies regarding the "comfort women" issue can be very distressful to the participants, as they are to the survivors. The Japanese government still seems reluctant in accepting full responsibility and apologizing sincerely to the survivors. Also, some government authorities and public figures still attempts to defame the survivors by repeated denials of the events.

\section{CONCLUSION}

We emphasize the importance of further research on offspring of "comfort women." Finding evidence of transgenerational transmission of trauma in offspring of the "comfort women" is important since it demonstrates the fact that the repercussion of the "comfort women" trauma is not confined 
to the victims themselves, and it would not be over even if all the remaining survivors pass away. Future studies should include more samples and adopt a more objective method.

\section{Acknowledgments}

This work was supported by a grant from the Korean Women's Development Institute and the Soonchunhyang University Research Fund.

The contents of the paper were previously published in Korean as part of the "2016 Comprehensive Report for the Resolution of Japanese 'Comfort Women' Issue" by the Korean Women's Development Institute. The Korean Women's Development Institute allowed us to publish this paper in Psychiatry Investigation.

\section{REFERENCES}

1. Lee J, Kwak YS, Kim YJ, Kim EJ, Park EJ, Shin Y, et al. Psychiatric sequelae of former "comfort women," survivors of the Japanese military sexual slavery during world war II. Psychiatry Investig 2018;15:336-343.

2. Kellerman NP. Psychopathology in children of Holocaust survivors: a review of the research literature. Isr J Psychiatry Relat Sci 2001;38:36-46.

3. Rowland-Klein D, Dunlop R. The transmission of trauma across generations: identification with parental trauma in children of Holocaust survivors. Aust N Z J Psychiatry 1998;32:358-369.

4. Levav I, Kohn R, Schwartz S. The psychiatric after-effects of the Holocaust on the second generation. Psychol Med 1998;28:755-760.

5. Brom D, Kfir R, Dasberg H. A controlled double-blind study on children of Holocaust survivors. Isr J Psychiatry Relat Sci 2001;38:47-57.

6. Freyberg JT. Difficulties in separation-individuation as experienced by offspring of Nazi holocaust survivors. Am J Orthopsychiatry 1980;50: 87-95.

7. Yehuda R, Schmeidler J, Wainberg M, Binder-Brynes K, Duvdevani T. Vulnerability to posttraumatic stress disorder in adult offspring of Holocaust survivors. Am J Psychiatry 1998;155:1163-1171.

8. Dekel R, Goldblatt H. Is there intergenerational transmission of trauma? The case of combat veterans' children. Am J Orthopsychiatry 2008; 78:281-289.

9. Daud A, Skoglund E, Rydelius PA. Children in families of torture vic- tims: transgenerational transmission of parents' traumatic experiences to their children. Int J Soc Welfare 2005;14:23-32.

10. Dalgaard NT, Todd BK, Daniel SI, Montgomery E. The transmission of trauma in refugee families: associations between intra-family trauma communication style, children's attachment security and psychosocial adjustment. Attach Hum Dev 2016;18:69-89.

11. Galovski T, Lyons JA. Psychological sequelae of combat violence: a review of the impact of PTSD on the veteran's family and possible interventions. Aggr Viol Behav 2004;9:477-501.

12. Sangalang CC, Jager J, Harachi TW. Effects of maternal traumatic distress on family functioning and child mental health: an examination of Southeast Asian refugee families in the US. Soc Sci Med 2017;184:178186.

13. First MB. Structured Clinical Interview for the DSM (SCID). Arlington: Wiley Online Library; 2015.

14. Juni S. Second-generation Holocaust survivors: psychological, theological, and moral challenges. J Trauma Dissociation 2016;17:97-111.

15. Field NP, Muong S, Sochanvimean V. Parental styles in the intergenerational transmission of trauma stemming from the Khmer Rouge Regime in Cambodia. Am J Orthopsychiatry 2013;83:483-494.

16. Ammerman RT, Putnam FW, Chard KM, Stevens J, Van Ginkel JB. PTSD in depressed mothers in home visitation. Psychol Trauma 2012;4.

17. Davidson AC, Mellor DJ. The adjustment of children of Australian Vietnam veterans: is there evidence for the transgenerational transmission of the effects of war-related trauma? Aust N Z J Psychiatry 2001; 35:345-351.

18. Ruscio AM, Weathers FW, King LA, King DW. Male war-zone veterans perceived relationships with their children: the importance of emotional numbing. J Trauma Stress 2002;15:351-357.

19. Yehuda R, Bierer LM. Transgenerational transmission of cortisol and PTSD risk. Prog Brain Res 2007;167:121-135.

20. Kellermann NP. Epigenetic transmission of holocaust trauma: can nightmares be inherited. Isr J Psychiatry Relat Sci 2013;50:33-39.

21. Meaney MJ, Szyf M. Environmental programming of stress responses through DNA methylation: life at the interface between a dynamic environment and a fixed genome. Dialogues Clin Neurosci 2005;7:103123. 